http://kitaibelia.unideb.hu/

ISSN 2064-4507 (Online) • ISSN 1219-9672 (Print)

(C) 2016, Department of Botany, University of Debrecen, Hungary

22 (1): 77-83.; 2017

DOI: $10.17542 /$ kit.22.77

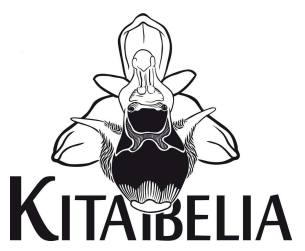

\title{
Adatok a színes békaszőlő (Potamogeton coloratus) hazai előfordulásához
}

\author{
MESTERHÁZY Attila ${ }^{1}$, VIDÉKI Róbert² ${ }^{2}$ LUKÁCS Balázs András ${ }^{3}$, \\ MÉSZÁros András ${ }^{4} \&$ MolnÁR V. Attila ${ }^{5}$
}

(1) Hortobágyi Nemzeti Park Igazgatóság, H-4024 Debrecen, Sumen u 2.

(2) Doronicum Kft., H-9794 Felsőcsatár, Petőfi u. 13.

(3) MTA Ökológiai Kutatóközpont DKI, Tisza-kutató Osztály, H-4026, Debrecen, Bem tér 18/C;

(4) Balaton-felvidéki Nemzeti Park Igazgatóság, H-8229 Csopak, Kossuth L. u. 16.

(5) Debreceni Egyetem TTK, Növénytani Tanszék, H-4032 Debrecen, Egyetem tér 1.; mva@science.unideb.hu

\section{Recent Hungarian distribution of Potamogeton coloratus}

\begin{abstract}
The distribution of fen pondweed (Potamogeton coloratus) restricted to Europe where it is one of the rarest and most threatened pondweed species. In Hungary, former data of fen pondweed originated mostly from thermal and karstic springs. Due to intensive bauxite mining activity in the edge of the Transdanubian Mountain Range (NW Hungary) these springs dried up by the end of the $20^{\text {th }}$ century, and it caused the temporal extinction of the species. After the ceasing of mining activity many of the former karstic springs have regenerated and several fen pondweed populations have reestablished. In this paper we summarized 18 population data of fen pondweed collected between 1999 and 2016. Many of them were formerly registered in the $19^{\text {th }}$ century too. Most of the new and rediscovered populations were found in karstic springs or in artificial and natural lakes in the vicinity of these springs.
\end{abstract}

Keywords: hydrophyte, karstic spring, karstic water, macrophyte, mining, Potamogetonaceae

Összefoglalás - Az európai elterjedésű színes békaszőlő (Potamogeton coloratus) a földrész egyik ritka és veszélyeztetett faja. Hazánkban korábbi adatai fóként termálvizes és karsztvizes források kifolyóiból származnak. A bauxitbányászat következtében ezek a Dunántúli-középhegység peremén lévő források elapadtak, a faj a 20. század utolsó évtizedeire eltűnt Magyarországról. A bányászat felhagyását követően a karsztvizek a legtöbb helyen újra felszínre törtek és a faj a korábbi élőhelyein ismét megjelent. A növényt1999 és 2016 között 18 lelőhelyről sikerült újra kimutatni, ezek jelentős részén már az 1900-as évek elején és közepén is gyűjtötték. A színes békaszőlő legtöbb előfordulása a karsztforrásokból került elő, de ezek környékén mesterséges és természetes tavakban is megtalálható.

Kulcsszavak: bányászat, hínár, karsztvíz, karsztforrások, makrofita, Potamogetonaceae

\section{Bevezetés}

A színes békaszőlő (Potamogeton coloratus Hornem.) az egyik legritkább és legveszélyeztetettebb európai hínárfaj (KLEINSTEUBER \& WolfF 1996, MOSER et al. 2002, KAPLAN 2010). Elterjedési területének nagyrésze földrészünkre esik, a legtöbb régióban kipusztult vagy nagyon megritkult fajként tartják számon. Európán kívül biztosan csak Törökországban ismert, ahol egyetlen gyűjtése Muğla tartományból (WIEGLB 1989) származik. Algériában (LECHEVALIER 
1952) előfordulása kétes, az Arábiai-félszigetről származó adata a Potamogeton nodosus-ra vonatkozik (KAPLAN \& SYMOENS 2005). Hazánkban mintegy húsz lelőhelyen került elő, de a 20. század utolsó évtizedeiben nem volt ismert aktuális előfordulása (BAUER 2006). Tápanyagokban szegény (oligotróf), jelentős mésztartalmú, tiszta, többnyire áramló vizek lakója, de néha nedves iszapon is megjelenik. Amint azt BoRos (1937) észrevette: „a hévizek gyakori kísérője... előszeretettel keresi a temperáltabb hőfokú vizeket”. FELFÖLDY (1990) a következőket írta a fajról: „A vízszennyezés és eredeti termőhelyeinek »meliorációja « miatt pusztulóban. Valamikor állományalkotó volt, de más hínárfajokkal társulva is előfordult. Mai hazai elterjedése ellenőrizendő!" Az utóbbi években a tematikus keresésének köszönhetően több korábbi előfordulási helyen ismét előkerült a faj. Közleményünk ezeket az adatokat igyekszik összefoglalni.

\section{Eredmények}

A Potamogeton coloratus 1999 és 2016 között 18 magyarországi lelőhelyen került elő, az előfordulási helyeket kistáj szerinti csoportosításban az alábbiakban részletezzük.

\section{Tapolcai-medence}

Raposka: Bánom-rét (N 46,85054 E 017,40650 [KEF 9170.1], 111 m tszf. m.). A BAUER (2006) által 2004-ben felfedezett állomány jelenleg is megvan. - Molnár V. A., Lukács B. A., 2016. 07. 29.

Raposka: Bánom-rét, Világos-patak mellékcsatornája: széleslevelű gyékényesben (Typhetum latifoliae), erőteljesen áramló vízben (N 46,85058 E 017,40645 [KEF 9170.1], $110 \mathrm{~m}$ tszf. m.). Borítási értékek a vízfelszín felett: Typha latifolia 5\%, Carex acutiformis 5\%, Berula erecta, 6\%, Bolboschoenus maritimus 3\%, Mentha aquatica 1\%, Schoenoplectus tabernaemontani +, vízfelszín alatt: Berula erecta 55\%, Potamogeton coloratus 5\%. Világos-patak mellékcsatornája: I. áteresz a murvás úton, a sodorvonalban nagy foltban (N 46,85053 E $017,40688^{\circ}$ [KEF 9170.1]). Világos-patak mellékcsatornája: II. áteresz a murvás úton, a sodorvonalban nagy foltban ( $\mathrm{N} 46,85015^{\circ} \mathrm{E} 017,40385^{\circ}$ [KEF 9170.1]). Mellékcsatorna partja, határozottan áramló vízben, nagy kiterjedésű foltban (N 46,84916 E 017,40796 [KEF 9170.3]). Zsombéksásos (Caricetum elatae) nagyméretü nyíltvizes semlyékeiben, szórványosan (N 46,84883 E 017,40861 [KEF 9170.3]). Csatornában, jelentős kiterjedésű területen (N 46,84768 ${ }^{\circ}$ E $017,40878^{\circ}$ [KEF 9170.3]) - Vidéki R., 2006. 07. 11. Széleslevelű gyékényesben (Typhetum latifoliae), folyamatosan áramló, 25 cm mély vizében. Borítási értékek: Typha latifolia 40\%, Potamogeton coloratus + , Carex elata + (N 46,84943 E 017,40488 [KEF 9170.3]), Vidéki R., 2006. 10. 02.

Raposka: Bozóti-dűlő, az élőhely-rekonstrukciós céllal ásott első mellékcsatornában (N 46,83983 E 017,40636 ${ }^{\circ}$ [KEF 9170.3], 116 m tszf. m.), Ceratophyllum demersum-mal Vidéki R., 2006. 07. 11. Az élőhely-rekonstrukciós céllal ásott első csatornában (N 46,84115 E $017,40605^{\circ}$ [KEF 9170.3]), összefüggő tömegben. A második csatornában (N 46,84115 E $017,40605^{\circ}$ [KEF 9170.3]) felszakadozott állomány - Vidéki R., 2006. 10. 02.

Lesencetomaj: Pénzes-rét, Világos-patak ( $\mathrm{N} 46,86790^{\circ} \mathrm{E} 017,39443^{\circ}$ és $\mathrm{N} 46,86078^{\circ} \mathrm{E}$ 017,39741ํ [KEF 9170.1], 116 m tszf. m.), csillárkamoszattal (Chara sp.) együtt. Világospatak forrás-csoportja. A buzgárok és a mederoldalról több ponton fakadó rétegforrások körül a terület kiszélesedik. A 10-15 cm mély mederben több ponton található felszakadozott állományban (N 46,87166 E 017,39610 [KEF 9170.1]) - Vidéki R., 2006. 08. 09. Ugyanitt forrásláp szivárgó vizében és nedves iszapján - Molnár V. A. \& Mészáros A., 2016. 08. 25.

Lesencetomaj: Bánom-rét, Világos-patak (N 46,85458 E 017,39993 [KEF 9170.1], $112 \mathrm{~m}$ tszf. m.), szőnyegszerű állomány. - Vidéki R., 2006. 10. 02. 


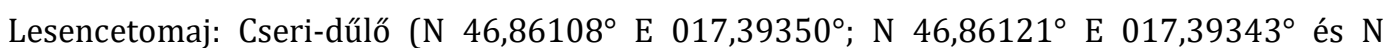
$46,86075^{\circ} \mathrm{E} 017,39376^{\circ}$ [KEF 9170.1], $116 \mathrm{~m}$ tszf. m.), csatorna erőteljesen áramló, 60$80 \mathrm{~cm}$ mély vizében több ponton tömeges - Vidéki R., 2006. 08. 09.

Lesencetomaj: Kalicsmajor, forrásban, a kavicsbánya mellett (N 46,52208 ${ }^{\circ}$ E 017,22406 ${ }^{\circ}$ [KEF 9170.1], 120 m tszf. m.), kis egyedszámban - Vidéki R., 2006. 07. 11.

Lesencetomaj: a 77-es út és a lesencetomaji bekötőút mellett, árok gyorsan áramló vizében

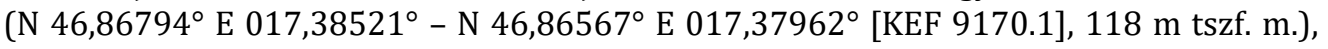
mintegy 500 méter hosszan, több foltban állományalkotó. - Molnár V. A. \& Mészáros A., 2016. 08. 25.

Tapolca: Alsó-köles-dűlő, horgásztóban (N 46,85575 E 017,42006º [KEF 9170.2], 110 m tszf. m.) - Vidéki R., 2006. 10. 02.

\section{Pápai-Bakonyalja}

Tapolcafő: a Tapolcafői-patakban és az Örvény-tó vizében ( $47,28267^{\circ}$ E $017,51827^{\circ}$ [KEF 8771.1], 172 m tszf. m.) - Mesterházy A., 2014. 04. 02., Molnár V. A. \& Lukács B. A. 2016. 07. 29.

Pápakovácsi-Attyapuszta: Attyai láprét, Asszonyka-kút (N 47,15376 E 017,31103 [KEF 8771.1], 191 m tszf. m.), kis egyedszámban - Mesterházy A., 2014. 06. 27. Ugyanitt Bauer Norbert is gyüjtötte (2015. 06. 07.).

\section{Vindornyai medence}

Vindornyalak: az egykori vindornyai láp elöntött magassásosában (N 46,53014 $\mathrm{E}$ 017,10248 [KEF 9169.1], $131 \mathrm{~m}$ tszf. m.) LÁJER (1999) adata. A közeli tőzeges tavakban lévő télisásos állományokban kis egyedszámban újra előkerült. Mesterházy A., (N 46,52398 ${ }^{\circ}$ 017,10168 [KEF 9169.1], 131 m tszf. m.) 2017.05.08.

\section{Sárrét}

Pétfürdő: a település belterületén, az egykori strand közelében, vizes árok áramló, sekély vizében (N 47,16390 E 018,12484 [KEF 8874.2], 124 m tszf. m.) - Molnár V. A., Lukács B. A. \& Mészáros A., 2016. 07. 29. és 08. 25.

\section{Dunamenti-síkság}

Vácrátót: a Tece-patak mentén, felhagyott tőzegbánya kazettáiban szórványosan (N 47,41503 E 019,13144ํ [KEF 8381.1], 133 m tszf. m.) - LÁJER (1999) adata, Mesterházy A., 2011. 06. 28.

\section{Marcal-medence}

Csabrendek: mesterséges tóban és csatornában nagy állomány (N 47,00343 E 017,15287 [KEF 8969.4], 141 m tszf. m.) - Mesterházy A. \& Király G., 2007. 05. 22.

Káptalanfa: zsombéksásos semlyékében, kis példányszámban (N 47,03431 E 017,17592 [KEF 8969.2], 156 m tszf. m.) - Mesterházy A., 2011. 05. 11.

Rigács: termálvíz kifolyójában több kiterjedt foltban (N 47,03354, E 017,14505 [KEF 8969.1], 150 tszf. m.) - ifj. Vasuta G., 2016. 10. 22. A 2017. januári bejárás során tapasztaltuk, hogy a csatornát kikotorták, a fajt nem találtuk.

\section{Hanság}

Lébény: Borászmajortól DNy-ra 0,9 km-re, sekély vizű csatornában tömeges ( $47,44315^{\circ} \mathrm{E}$ 017,20326 [KEF 8270.3], 112 m tszf. m.) - KIRÁLY et al. (2015) adata. 


\section{Az eredmények megvitatása}

A jelenleg ismert állományok 3 féle élőhelytípusban fordulnak elő:

Karsztforrások kifolyói és felső szakaszuk: A faj előfordulásai legnagyobbrészt karsztforrások kifolyóiból ismertek, melyek hőmérséklete egész évben közel állandó. Itt nem csak a forráskifolyóban, hanem gyakran a patakok felső, még nem szennyezett szakaszán is megtalálható. A forrástól távolodva ezek a vízfolyások egyre inkább ingadozó hőmérsékletűek lesznek, valószínúleg ez és a vizek növekvő szervesanyag tartalma a magyarázata, hogy a növény az alsóbb szakaszokon nem fordul elő. Ezekre az élőhelyekre is jellemző a csillárka (Chara spp.) és fénycsillárka (Nitella spp.) fajok előfordulása. A faj élőhelyválasztására vonatkozó korábbi megállapítások ezt a típust tartják a faj jellemző élőhelyének (BoRos 1937, BAUER 2006).

Mesterséges víztestek (tőzegbányagödrök, csatornák): A színes békaszőlő a korábban itt található természetes élőhelyeken (tavak, források) fordulhatott elő, amelyeket meliorációs munkák során lecsapoltak. A faj ezek után vagy az élőhelyet átszelő árokban élt tovább, vagy az újonnan létesített mesterséges víztestekben, a magbank segítségével tudott új populációt létrehozni.

Természetes tavak: Ilyen típusú élőhelyről a fajnak jelenleg csak egy adata ismert a Marcal-medencéből. A Szentimrefalva melletti előfordulás egy ritkán kiszáradó legelőn lévő tavacska zsombéksásos állományának közepén van, ahol a mintegy 1 méteres mélységú vízben más békaszőlő (Potamogeton gramineus, P. natans) és csillárka fajok (Chara hispida, C. fragilis) mellett él. Feltételezésünk szerint a faj olyan, ritkán kiszáradó kis tavakban is előfordulhatott, amelyek nemcsak csapadékból, hanem talajvízből vagy forrásból is kaptak vízutánpótlást. Ezek csillárka fajokban gazdag mezotróf vagy esetenként oligotróf élőhelyek lehettek. Az ilyen jellegű élőhelyek hazánkban nagyrészt megsemmisültek.

A jelenleg ismert lelőhelyek közül 7 korábban is ismert volt, de néhány évtizedre látszólag eltűnt. Legtöbb hazai előfordulása a Dunántúlon (a Tapolcai-medencében és a Bakonyalján) vált ismertté. Számos lelőhelye (Tapolca, Raposka, Tapolcafő, Pétfürdő, Tata) karsztforrások kifolyóiban volt ismert. A karsztforrások temperált vizet adnak, hőmérsékletük egész évben nagyrészt állandó. JASKó (1935) mérései szerint a tapolcafői források vízhőmérséklete rendkívül csekély $\left(14-17{ }^{\circ} \mathrm{C}\right.$ közötti) éves ingadozást mutat. BoRos (1937) a tapolcai források esetében $16-18{ }^{\circ} \mathrm{C}-$ os vízhőmérsékletet említett, ugyanitt BAUER (2006) 15,7 ${ }^{\circ} \mathrm{C}$-ot mért. Ezeknek a karsztforrásokban élő állományoknak az időleges eltűnésében jelentős szerepet játszott az a tény, hogy 1962-től kezdődően a Bakonyi Bauxitbányák Vállalat Halimba, Nyirád, Szőc, Kislőd és néhány más település határában „aktív vízvédelemmel” kezdett el bauxitot kitermelni (BENKE 1997). Ennek során függőleges aknákban elhelyezett búvárszivattyúkkal emelték ki a vizet, így a helyi vízszint csökkenését érték el és így vízmentes körülmények között bányászhattak. Emiatt a karsztvízszint a területen drasztikusan lecsökkent, a források elapadtak, az általuk fenntartott életközösségek átalakultak, fajaik többsége eltűnt. 1989-ben a bauxitbányászat hanyatlásával megszűnt a karsztvíz kiemelése, ám ezt követően még közel másfél évtizedbe telt míg a karsztforrások ismét megindultak. A karsztforrások regenerálódása jelentős szerepet játszott abban, hogy a faj több állománya regenerálódhatott.

A fajt korábban más jellegű termőhelyekről is közölték, ezek az adatok tévesek vagy kétesek. Természetes időszakos vízállásból, a Pomáz melletti Kő-hegyen gyűjtötte Lengyel Géza 1903-ban (BP). A herbáriumi lapon egyetlen békaszőlő példány látható bőrnemü úszólevelekkel, amely véleményünk szerint Potamogeton natans vegetatív egyede. Szintén a téves adatok közé tartozik a balatonfelvidéki Kornyi-tóból származó példány, melyet 1925-ben gyűjtött Jávorka Sándor. A lapon egy széleslevelű békaszőlőfaj (Potamogeton natans vagy $P$. nodosus) juvenilis egyede látható. 


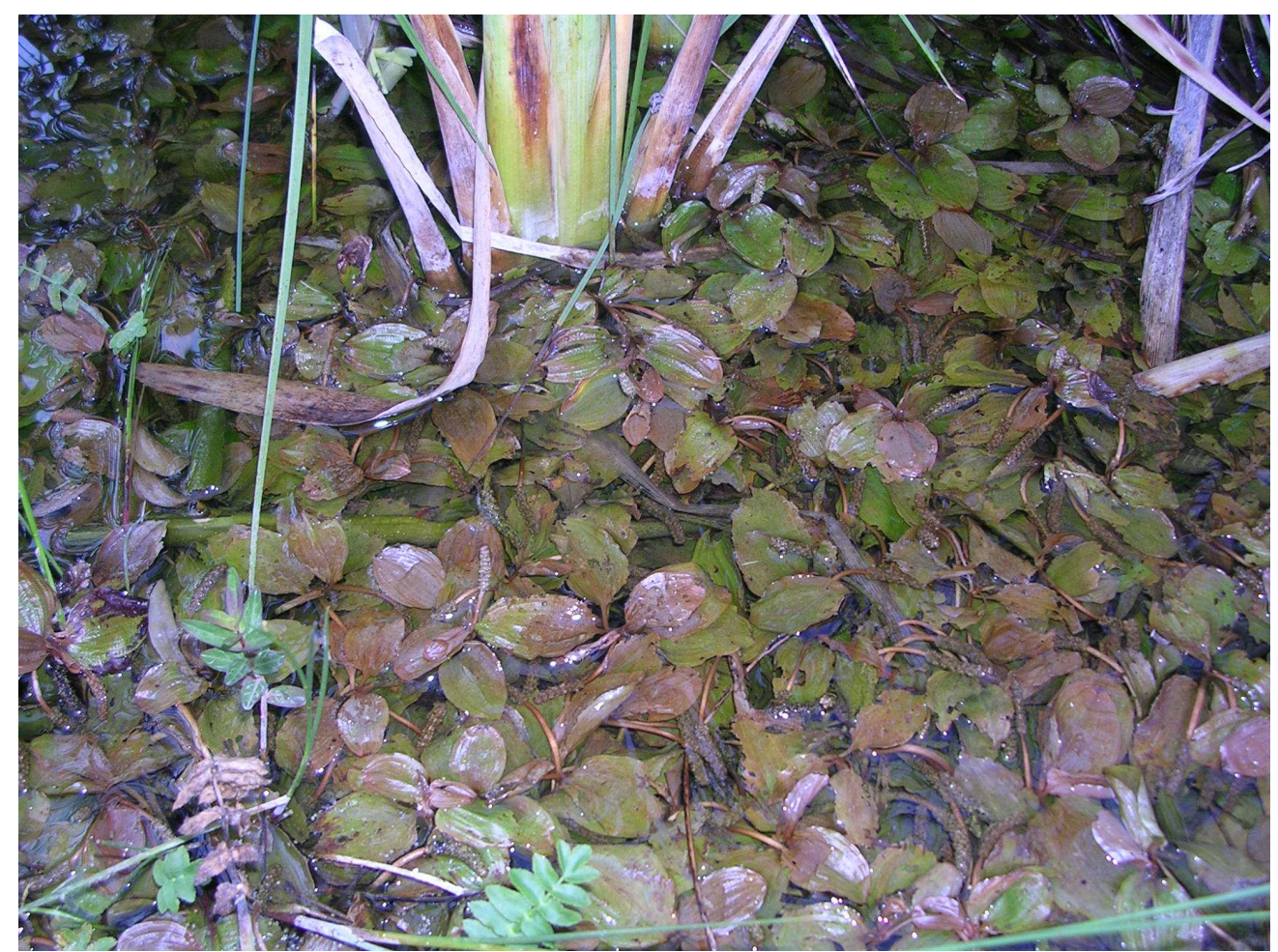

1. ábra. A színes békaszőlő előfordulása állóvízben (Lesencetomaj) (Mesterházy A. felvétele) Fig. 1. Potamogeton coloratus in stagnant water (Lesencetomaj) (photo of A. Mesterházy)

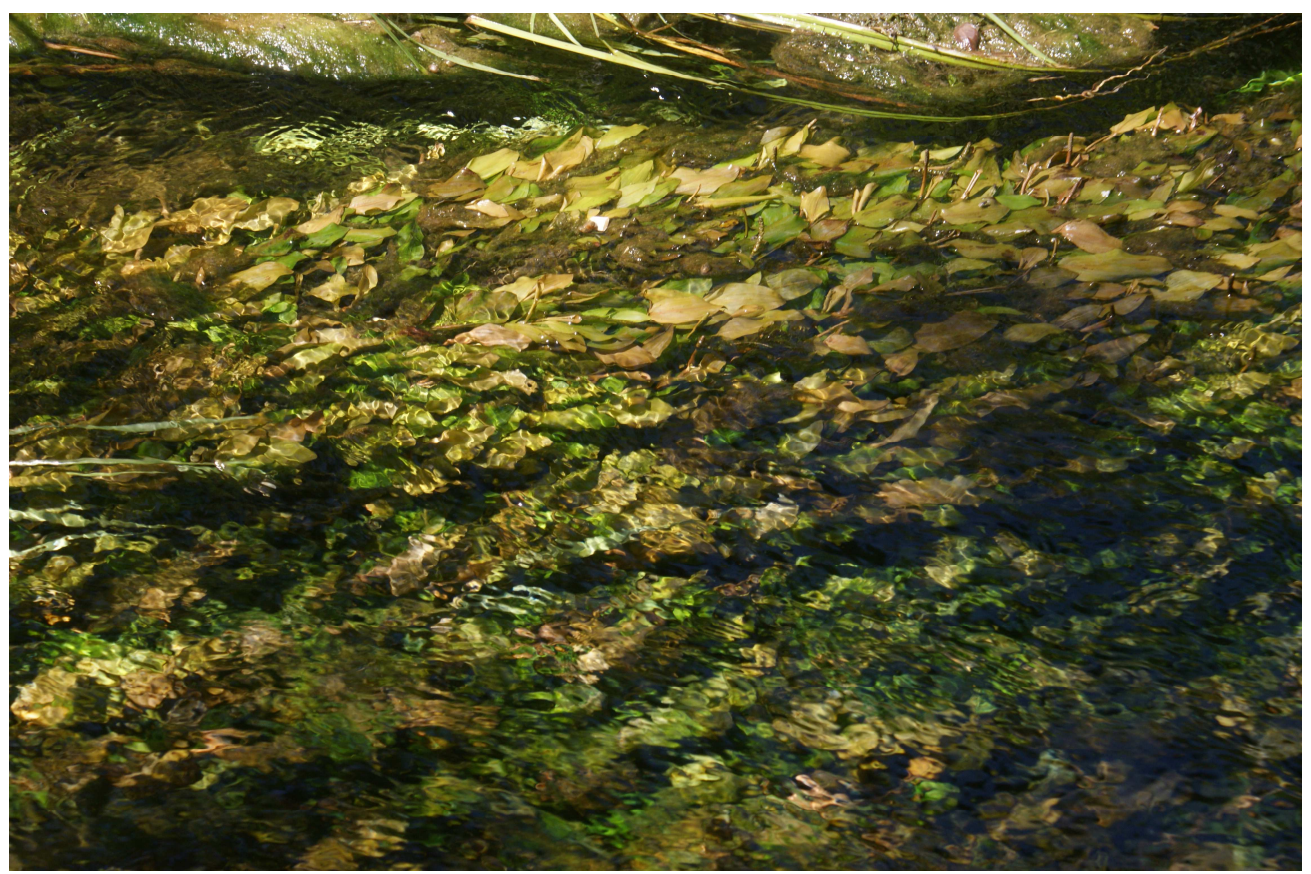

2. ábra. A színes békaszőlő előfordulása gyorsan áramló vízben (Tapolcafő) (Molnár V. A. felvétele) Fig. 2. Potamogeton coloratus in fast-flowing fresh water (Tapolcafő) (photo of A. Molnár V.) 
Kétes adatként kell értékelnünk Toborffy Zoltán 1971-es gyűjtését, mely a vas megyei Csörnöc-patakból származik. Bár az itt talált példány egyértelműen a $P$. coloratus-hoz tartozik, véleményünk szerint az élőhely (lassú folyású, alkalikus, oxigénben szegény víz) ismeretében ebben az esetben a példány elcseréléséről vagy félrecédulázásról lehet szó. A fajt egy több helyszínt érintő terepgyakorlat során gyűjtötték és valószínűsíthető, hogy egy másik nap gyűjtéséhez adták hozzá a „Nagymizdó: Csörnöc-patak” cédulát.

Arra nézve, hogy az utóbbi években újrafelfedezett lelőhelyeken miként vészelte át a faj a számára kedvezőtlen mintegy három évtizedes időszakot, cseh kutatók tanulmánya ad választ. KAPLAN et al. (2014) arról számoltak be, hogy a Csehországban utoljára 1977-ben észlelt fajnak 2004-től kezdődően sikerrel állították helyre egy korábbi állományát és hoztak létre egy újat a talajban megtalálható tartós magbank segítségével.

Az újrafelfedezett élőhelyeken szemrevételezett élőhelyi- és limnológiai jellemzők alapján mi is igazolni látjuk, hogy a színes békaszőlő kifejezetten igényli a tápanyagszegény, oxigénben gazdag, meszes vizeket és a termőhely eutrofizációját nem viseli el. Bár megtalálható nedves iszapfelszíneken is, az állandó vízellátottságú víztestekben érzi magát jól. Állóvizekben (1. ábra) (például Tapolcafő: Örvény-tó) és gyors folyású patakokban (2. ábra) (Világospatak, Tapolcafői-patak) egyaránt megtalálható. Megfigyeléseink megerősítik a cseh kutatók eredményeit (KAPLAN et al. 2014), akik rámutatnak arra, hogy a faj magja a talajban hosszú ideig életképes tud maradni. Az elmúlt évtizedben történ megfigyelések előtt, a botanikusok által viszonylag gyakran látogatott Attyai-forrásból 1938-ban, míg a tapolcafői Malom-tóban 1966-ban gyűjtötték utoljára. A karsztvízszint csökkenése miatt mindkét forrás elapadt, csak a 90-es évek közepén múködtek újra. A 90-es évek elejéig a tapolcafői élőhelyen lucfenyő- és nemesnyár ültetvény volt, míg az attyai forrás (Asszonyka-kút) környékén a mai láprétek helyén mezőgazdasági művelés folyt. A faj magjai képesek voltak túlélni a termőhely szinte teljes kiszáradását, hogy félévszázad múlva újra visszatérjenek a karsztvízzel együtt, rászolgálva ezzel Boros (1937) jellemzésre („A therma-k hü kísérője”).

\section{Köszönetnyilvánítás}

Köszönjük ifj. Vasuta Gábornak a rigácsi lelőhellyel kapcsolatos közléseit. A munkát az OTKA K108992 és OTKA PD 120775 számú pályázat támogatta.

\section{Irodalom}

Bauer N. (2006): A Potamogeton coloratus Hornem. Magyarországon. - Flora Pannonica 4: 111-119.

BENKE I. (szerk.) (1997): A magyar bányászat évezredes története I-II. - Országos Magyar Bányászati és Kohászati Egyesület, 695 ill. 752 pp.

BoRos Á. (1937): A magyarországi hévizek felsőbbrendű növényzete. - Botanikai Közlemények 34: 85-118. FELFÖLDY L. (1990): Hínárhatározó. - Vízügyi Hidrobiológia 18., VIZDOK, Budapest, 144 pp.

LÁJER K. (1999): Florisztikai adatok a Dunántúlról, valamint Vácrátót környékéről. - Kitaibelia 4 (2): 311-317.

KAPlan Z. (2010): Potamogetonaceae Dumort. - rdestovité. - In: ŠTĚPÁnKovÁ J., CHRTeK J. \& KAPLAN Z. (eds), Květena České republiky, vol. 8., Academia, Praha, pp. 329-384.

Kaplan Z. \& Symoens J.J. (2005): Taxonomy, distribution and nomenclature of three confused broadleaved Potamogeton species occurring in Africa and on surrounding islands. - Botanical Journal of the Linnean Society 148: 329-357.

KAPlan Z., Šumberová K., Formanová I. \& DuChÁčEK M. (2014): Re-establishment of an extinct population of the endangered aquatic plant Potamogeton coloratus. - Aquatic Botany 119: 91-99.

KIRÁLY G., TAKÁCS G. \& KIRÁLY A. (2015): Adatok a Kisalföld flórájához és növényföldrajzához. - Kitaibelia 20 (2): 235-253.

Kleinsteuber A. \& WolfF P. (1996): Potamogeton polygonifolius und Potamogeton coloratus in BadenWürttenberg. - Carolinea 54: 180-183. 
LEChEVAlier P. (ed.) (1952): Flore de l'Afrique du Nord. Vol. 1. - Rou de Tournon, Paris, 366 pp.

Mesterházy A. (2006): „A therma-k hű kísérője”. - In: Ujhelyi P. \& Molnár V. A. (szerk.), Élővilág Enciklopédia II. Kossuth Kiadó, Budapest, p. 147.

Moser D., GygaX A., Bäumler B., Wyler N. \& PAlese R. (2002): Rote Liste der gefährdeten Farn- und Blütenpflanzen der Schweiz [Red List of the Threatened Ferns and Flowering Plants of Switzerland]. Bundesamt für Umwelt, Wald und Land-schaft, Bern; Zentrum des Datenverbundnetzes der Schweizer Flora, Chambésy; Conservatoire et Jardin botaniques de la Ville de Genève.

JASKó S. (1935): A Pápai Bakony hidrológiája. - Hidrológiai Közlöny 15: 205-211.

Wieglb G. (1989): On Potamogeton coloratus (Potamogatonaceae) in Turkey. - Willdenowia 19: 121-125.

Beérkezett: 2017. 03. 12. • Elfogadva: 2017. 04. 19. 